\title{
Bioethanol production from marine algae biomass: prospect and troubles
}

\author{
Sản xuất ethanol tù̀ sinh khối tảo: triển vọng và khó khăn \\ Review paper
}

Nguyen, Thi Hong Minh; Vu, Van Hanh*

Institute of Biotechnology, Vietnam Academy of Science and Technology, 18 Hoang Quoc Viet, Hanoi, Vietnam

\begin{abstract}
The increase of petroleum cost as well as global warming and climate change result in investigation to discover new renewable energy resources. Bioenergy is one of the most important sources that is concerning the scientists and industrial sector. Although bioethanol had to be known as one of the most important renewable energy sources in order to reduce greenhouse gases and global warming, there is a limited number of publications reporting on them. In this review, a brief overview is offered about bioethanol production from algae. It can be given a deeper insight in dificulties and promising potential of bioethanol from algae.
\end{abstract}

Sư gia tăng giá nhiên liệu hóa thạch cùng với cảnh báo toàn cầu về biến đổi khí hậu huớng đến việc nghiên cứu tìm ra nhũng nguồn năng luợng có thể tái tạo. Năng luợng sinh học là một trong nhũng nguồn quan trọng được các nhà khoa học và doanh nghiệp quan tâm. Mặc dù ethanol sinh học đã được biết đến nhu là một trong nhũng dạng năng luợng tái tạo quan trọng nhất để giảm thiểu các khí nhà kính và cảnh báo toàn cầu, nhưng chỉ có một số it bài báo về nó. Trong bài tổng quan này, chúng tôi giới thiệu vắn tắt việc sản xuất ethanol sinh học tù̀ tảo. Nó đua ra cái nhìn sâu hơn về những khó khăn và tiềm năng hứa hẹn của sản xuất ethanol sinh học từ tảo.

Keywords: biofuel, bioethanol, biomass, renewable energy, fossil fuel, algae

\section{Introduction}

In 2008, fossil fuels accounted for $88 \%$ of the global primary energy consumption (Brennan and Owende, 2010). However, the use of fossil fuels is now widely accepted as unsustainable due to depleting resources and the accumulation of greenhouse gases in the environment (Schenk et al., 2008). It has become increasingly important to develop abatement techniques and adopt policies to promote those renewable energy sources dued to minimize the dependency on fossil reserves and also to maintain environmental and economic sustainability (Brennan and Owende, 2010; Prasad et al., 2007a,b; Singh et al., 2010a,b).

Biofuels are expected to reduce dependence on imported petroleum with associated political and economic vulnerability, reduce greenhouse gas emissions and other pollutants, and revitalize the economy by increasing demand and prices for agricultural products (Darici and Ocal, 2010; Tatli, 2009; Balat, 2010). Biofuels are an attractive alternative to current petroleum based fuels as they can be utilized as transportation fuels with little change to current technologies and have significant potential to improve sustainability (Carere et al., 2008). There are two global liquid transportation biofuels: bioethanol and biodiesel, respectively (Demirbas, 2011). Bioethanol is good alternate fuel that is produced almost entirely from food crops (Hammond et al., 2008, Tan et al., 2009, Börjesson, 2009).

All automobile manufacturers produce vehicles that can readily use $10 \%$ ethanol or $85 \%$ ethanol (E85) blends for fuel, and ethanol can replace diesel in heavy vehicles as well. Nearly all fuel ethanol is produced by fermentation of corn glucose in the United States or sucrose in Brazil (Rosillo-Calle and Cortez, 1998). Generally, ethanol can be derived from any material that contains sugar. Today, raw materials used in the manufacture of ethanol by fermentation are classified as sugars, starches and cellulosic materials (Bailey and Ollis, 1986). Sugars can be converted to ethanol directly, while starches first have to be hydrolysed to fermentable sugars by the action of enzymes. Cellulose must likewise be converted to sugars before further fermentation, generally by the action of mineral acids (Bashir and Lee, 1994).

Research on improving bioethanol production has been accelerating for both ecological and economical reasons, 
primarily for its use as an alternative to petroleum based fuels (Prasad et al., 2007a). However, depleting water resources and utilization of arable land have put the feasibility of bioethanol under the scanner. The water footprint and land use for the production of biomass by cultivating various energy crops is given in Table 1 . The extremely large arable land utilization for biomass production to be used as a raw material for production of bioeth- anol as well as biofuels could result in shortages in basic foods, such as corn, cereals, soy, mustard, barley, etc. Thus, they have brought much controversy and debate on their sustainability (Goh and Lee, 2010). In this respect, cultivation of algae at sea water or industrial or other wastewater provides a possible solution for this energy issue.

Table 1. Water footprint, land use and bioethanol yield of various energy crops

\begin{tabular}{|c|c|c|c|c|}
\hline & $\begin{array}{l}\text { Water footprint } \\
\qquad\left(\mathrm{m}^{\mathbf{3}} \mathbf{G} \mathbf{J}^{-1}\right)\end{array}$ & $\begin{array}{l}\text { Land use } \\
\left(\mathrm{m}^{2} \mathrm{GJ}^{-1}\right)\end{array}$ & $\begin{array}{r}\text { Energy } \\
\left(G^{-1} \mathrm{ha}^{-1} \mathbf{a}^{-1}\right)\end{array}$ & $\begin{array}{r}\text { Biofuel yield } \\
\left(\mathrm{L} \mathrm{ha}^{-1} \mathrm{a}^{-1}\right)\end{array}$ \\
\hline Cassava & 148 & 79 & 126 & 6,000 \\
\hline Wheat & 93 & 305 & 33 & 1,56 \\
\hline Paddy rice & 85 & 212 & 47 & 2,25 \\
\hline Corn grain & 50 & 133 & 75 & $3,5^{\prime}$ \\
\hline Potatoes & 105 & 114 & 88 & 4,167 \\
\hline Sugar cane & 50 & 81 & 124 & 5,8 \\
\hline Sugar beet & 46 & 95 & 105 & 5,000 \\
\hline Sorghum & 180 & 386 & 26 & 1,23 \\
\hline Soybean & 383 & 386 & 26 & 1,23 \\
\hline
\end{tabular}

Note: The above table was reviewed by Singh et al., 2011

Algae are considered as the only alternative to current bioethanol crops such as corn and soybean as they do not require arable land (Chisti, 2007; Hu et al., 2008; Singh et al., 2010c). The arable land could be used efficiently to grow food crops rather than biomass and oil seed crops for the production of biofuels. Water filled areas that are not suitable for growing food crops and industrial waste water can be used for the cultivation of algal biomass without any compromise with land and water resource for the production of bioethanol that will also not adversely affect the food cost (Singh et al., 2011). In addition, algae can be converted directly into energy, such as biodiesel, bioethanol and biomethanol and therefore can be a source of renewable energy.

\section{Ethanol production from microal- gae}

Marine microalgae, or phytoplankton, are mostly represented in ocean populations: the best known are the diatoms (Bacillariophyta), the dinoflagellates (Dinophyta), the green algae (Chlorophyta) and the blue-green algae (Cyanophyta). The unicellular marine microalgae were considered to be an abounding resource for carotenoids, lipids, and polysaccharides, and were widely investigated in the fields of food supplements and bio-fuel production (Liau et al., 2010). While terrestrial plants in temperate climates can achieve a photoconversion efficiency of only below $1 \%$, microalgae can convert up to $5 \%$ of the solar energy into chemical energy (Rösch et al., 2012). Microalgae can be converted to biodiesel, bioethanol, bio-oil, biohydrogen and biomethane via thermochemical and biochemical methods (Demirbas, 2011). Using microalgae as a source of biofuels is not a new idea (Chisti, 1980), but it is now being taken seriously because of the increasing cost of petroleum and, more significantly, the emerging concern about global warming arising from burning fossil fuels (Sawayama et al., 1995).

Certain species of microalgae have the ability of producing high levels of carbohydrates instead of lipids as reserve polymers. These species are ideal candidates for the production of bioethanol as carbohydrates from microalgae can be extracted to produce fermentable sugars. It has been estimated that approximately 5000-15,000 gal of ethanol/acre/year (46,760-140,290 L/ha) can be produced from microalgae. This yield is several orders of magnitude larger than yields obtained for other feedstocks (Table 2). Blue-green algae including Spirogyra species and Chlorococum sp. have been shown to accumulate high levels of polysaccharides both in their complex cell walls and as starch. This starch accumulation can be used in the production of bioethanol (Harun et al., 2010; Eshaq et al., 2011). Harun et al. have shown that the blue-green algae Chlorococum sp. produces $60 \%$ higher ethanol concentrations for samples that are pre-extracted for lipids versus those that remain as dried intact cells. This indicates that microalgae can be used for the production of both lipidbased biofuels and for ethanol biofuels from the same biomass as a means to increase their overall economic value (Jones and Mayfield, 2012).

The microalgae Chlorella vulgaris, particularly, has been considered as a promising feedstock for bioethanol production because it can accumulate up to $37 \%$ (dry weight) of starch. However, higher starch contents can also be obtained for optimized culture conditions (Hirano et al., 1997). Chlorococum sp. was also used as a substrate for bioethanol production under different fermentation conditions. Results showed a maximum bioethanol concentration of $3.83 \mathrm{~g} / \mathrm{L}$ obtained from $10 \mathrm{~g} / \mathrm{L}$ of lipid-extracted microalgae debris (Harun et al., 2009). 
Table 2. Ethanol yield from different sources

\begin{tabular}{lcc} 
Source & $\begin{array}{c}\text { Ethanol yield } \\
\text { (gal/acre) }\end{array}$ & $\begin{array}{c}\text { Ethanol yield } \\
\text { (L/ha) }\end{array}$ \\
\hline Corn stover & $112-150$ & $1,050-1,400$ \\
Wheat & 277 & 2,590 \\
Cassava & 354 & 3,310 \\
Sweet sorghum & $326-435$ & $3,050-4,070$ \\
Corn & $370-430$ & $3,460-4,020$ \\
Sugar beet & $536-714$ & $5,010-6,680$ \\
Switch grass & 1,150 & 10,760 \\
Microalgae & $5,000-15,000$ & $46,760-140,290$
\end{tabular}

Note: The above table was reviewed by Mussatto et al., 2010
Bioethanol production from microalgae begins with the collection and drying of algae that have been cultivated in a suitable for water environment. In the next step of the process, the algae mass is ground and hydrolyzed and then the hydrolyzed mass is fermented and finally distilled (Demirbas and Demirbas, 2010). Production of ethanol by using microalgal as raw material can be performed according to the following procedure. In the first step, the starch of microalgae is released from the cells with the aid of mechanical equipment or an enzyme. When the cells begin to degrade, Saccharomycess cerevisiae yeast is added to the biomass to begin fermentation. The product of fermentation is ethanol. The ethanol is drained from the tank and pumped to a holding tank to be fed to a distillation unit. Ethanol was produced with microalgal photosynthesis and intracellular anaerobic fermentation (Hirano et al., 1997; Pimentel, 2003; Pimentel and Patzek, 2005; Demirbas, 2011). One hectare algae farm on wasteland can produce over 10-100 times of oil as compared to any other known source of oil-crops. While a crop cycle may take from three months to three years for production, algae can start producing oil within 3-5 days and thereafter oil can be harvested on daily basis.

\section{Ethanol production from macroal- gae}

Seaweeds are classified into three groups: green, brown, and red, and they contain various types of glucans which are polysaccharides composed of glucose, though the concentration of these glucans is known to be relatively low. Seaweed was proposed as one of the most promising biomass materials that can be easily converted to ethanol, since seaweeds are known to contain a low concentration of lignin or no lignin at all. Three types of seaweed including sea lettuce, chigaiso, and agar weed were used as representatives of green, brown, and red seaweeds, respectively, and methods for obtaining high concentrations of ethanol (bioethanol) from these seaweeds were investigated (Yanagisawa et al., 2011). An ethanol yield of more than $3 \%$ was obtained from these seaweeds.

Today, the most important microorganisms applied for ethanol production are the yeast Saccharomyces cerevisiae and the bacterium Zymomonas mobilis. However, both these ethanol producers have a very narrow substrate range. Horn et al. have reported that Zymobacter palmae could produce ethanol from mannitol in seaweed extract, if some supply of oxygen was provided. In addition, the possibility of ethanol production from Laminaria hyperborean extracts was evaluated, focusing on the yeast Pichia angophorae and its potential of utilising both mannitol and laminaran as substrates. Initial experiments with seaweed extract showed that Pichia angophorae was able to utilise both mannitol and laminaran for ethanol production (Horn, 2000b). Ethanol can be produced from the mannitol and laminaran contained in extracts from $L$. hyperborea fronds. Z. palmae was able to produce ethanol from mannitol, while $P$. angophorae could utilise both carbohydrates for ethanol production.

Bioethanol from algae holds significant potential due to their low percentage of lignin and hemicellulose as compared to other lignocellulosic plants (Harun et al., 2010). While having low lignin content, macroalgae contain significant amount of sugars (at least $50 \%$ ) that could be used in fermentation for bioethanol production (Wi et al., 2009). However, in certain marine algae such as red algae the carbohydrate content is influenced by the presence of agar, a polymer of galactose and galactopyranose. Current research seeks to develop methods of saccharification to unlock galactose from the agar and further release glucose from cellulose leading to higher ethanol yields during fermentation (Wi et al., 2009; Yoon et al., 2010).

\section{Trends and challenges of bioethanol production from algae}

Ethanol production worldwide has strongly increased since the oil crises in 1970. Its market grew from less than a billion litters in 1975 to more than 39 billion litters in 2006, and is expected to reach 100 billion litters in 2015 (Licht, 2006). The international ethanol market has been stimulated by governmental politics of incentive to the use of renewable fuels. Although in expansion, the international market is very regional, with the largest producers being also the largest consumers (Mussatto et al., 2010). Brazil was the main exporter (3.5 gal), and the United States, Japan and the Europe were the main importers. In Brazil, the ethanol use as bio-fuel is very common. In the $80 \mathrm{~s}$, more than half of the Brazilian cars used $95 \%$ anhydrous ethanol, however, the lack of sugar and its high prices decreased this value in the subsequent years (Solomon et al., 2007). Nowadays, almost all the Brazilian vehicles use ethanol, in the pure form or in 
mixture with the gasoline, where ethanol corresponds up to $25 \%$ of the mixture. In the United States, ethanol is actually used in two forms: mixed with gasoline in the maximum proportion of $10 \%$, or in mixtures containing $85 \%$ ethanol and $15 \%$ gasoline, as an alternative fuel (EIA, 2006). In a next step, the supply of ethanol mixtures with gasoline will be expanded to the whole country and some efforts will be also directed to increase the ethanol percentage in the mixture to $10 \%$ (Prasad et al., 2007b).

Although bioethanol used as renewable fuel is one of the positive trends for sustainable development, there are some difficulties in production and consumption. Ethanol is an intermediate in the complete digestion of organic material and is produced by specific microbial strains. An obvious practical problem with ethanol production is that the microbial culture may have to be protected against contamination of other microbes. Thus, ethanol production should take place under controlled conditions to prevent contamination problems (Horn et al., 2000a,b).

The complex composition of seaweeds makes it a difficult substrate to ferment to ethanol by one or a few strains of microbes. There are a number of limited researchs done on ethanol production from seaweeds. The reason may be the complex composition of seaweeds, containing several different carbohydrates. Finding a microorganism that can ferment all the different carbohydrates to ethanol is not very likely. Besides, alginate, as a major component in brown algae, may not be fermented to ethanol since the redox balance in the glycolytic oxidation of uronic acids to pyruvate is maintained. Moreover, utilisation of seaweed carbohydrates for ethanol production is probably only of economic interest when integrated with a balanced and total utilisation of the seaweed material. Energy production from seaweeds will only be economic if the harvesting costs are low. Conversion of biomass from marine algae into ethanol could be economically feasible since some algae hydrolysates can contain more total carbohydrate and hexose sugars than some terrestrial,lignocellulosic biomass feedstock (Horn, 2000).

\section{Conclusions}

Bioethanol production from marine algae has great potential for sustainable development. Several algae species have been studied for, such as Spirogyra species, Chlorococum sp., Chlorella vulgaris, and Laminaria hyperborean. However, there have been difficulties in order to widely commercialize bioethanol as an alternative to petroleum based fuels, and it needs more studies in the future to dissolve these troubles.

\section{References}

[1] Bailey, J.E., Ollis, D.F. 1986. Biochemical engineering fundamentals, $2^{\text {nd }}$ ed., Mc Graw-Hill, Inc.

[2] Balat, H. 2010. Prospects of biofuels for a sustainable energy future: a critical 21.

[3] Bashir, S., Lee, S. 1994. Fuel ethanol production from agricultural lignocellulose feedstocks - a review. Fuel Science Technol. Int'1. 12: 1427-1473.
[4] Börjesson, P. 2009. Good or bad bioethanol from a greenhouse gas perspective - what determines this? Appl Energy, 86: 589-94.

[5] Brennan, L., Owende, P. 2010. Biofuels from microalgae-a review of technologies for production, processing, and extractions of biofuels and co-products. Renew. Sustain. Energy Rev. 14: 557-577.

[6] Carere, C. R., Sparling, R., Cicek, N., Levin, D. B. 2008. Third generation biofuels via direct cellulose fermentation. Int. J. Mol. Sci. 9: 1342-1360.

[7] Chisti, M. Y. 1980. An unusual hydrocarbon. J Ramsay Soc. 27-28: 24-6.

[8] Chisti, Y. 2007. Biodiesel from microalgae. Biotechnol. Adv. 25: 294-306.

[9] Darici, B., Ocal, F. M. 2010. The structure of European financial system and financial integration. Energy Educ Sci Technol Part B. 2: 133-45.

[10] Demirbas. A., Demirbas, M.F. 2010. Algae energy: algae as a new source of biodiesel. London: Springer-Verlag.

[11] Demirbas, M. F. 2011. Biofuels from algae for sustainable development. Applied Energy. 88: 34733480 .

[12] Eshaq, F. S., Ali, M. N., Mohd, M. K. 2011. Production of bioethanol from next generation feed-stock alga Spirogyra species. Int J Eng Sci Technol. 3: 1749-1755.

[13] Goh, C. S., Lee, K. T. 2010. A visionary and conceptual macroalgae-based third- eneration bioethanol (TGB) biorefinery in Sabah, Malaysia as an underlay for renewable and sustainable development. Renew. Sustain.Energy Rev. 14: 842-848.

[14] Hammond, G. P., Kallu, S., McManus, M. C. 2008. Development of biofuels for the UK automotive market. Appl Energy. 85: 506-15.

[15] Harun, R., Danquah, M. K., Forde, G. M. 2009. Microalgal biomass as a fermentation feedstock for bioethanol production. J Chem Technol Biotechnol. 85: 199-203.

[16] Harun, R., Danquah, M.K., Forde, G.M. 2010. Microalgal biomass as a fermentation feedstock for bioethanol production. J Chem Technol Biotechnol. 85: 199-203.

[17] Hirano, A., Ueda, R., Hirayama, S. 1997. $\mathrm{CO}_{2}$ fixation and ethanol production with microalgal photosynthesis and intracellular anaerobic fermentation. Energy. 22: 137-42.

[18] Horn, S. J. 2000. Bioenergy from brown seaweeds. Thesis of doctor degree, Norwegian University of Science and Technology NTNU.

[19] Horn, S. J., Aasen I. M., and Østgaard, K. 2000a. Production of ethanol from mannitol by Zymobacter palmae. J. ind. Microbiol. Biotechnol. 24: 51-57.

[20] Horn, S. J., Aasen, I. M., and Østgaard, K. 2000 b. Ethanol production from seaweed extract. J. ind. Microbiol. Biotechnol. J. ind. Microbiol. Biotechnol. 
25: 249-254.

[21] Hu, Q., Sommerfeld, M., Jarvis, E., Ghirardi, M., Posewitz, M., Seibert, M., Darzins, A. 2008. Microalgal triacylglycerols as feedstocks for biofuel production: perspectives and advances. Plant J. 54: 621-639.

[22] Jones, C. S., and Mayfield, S. P. 2012. Algae biofuels: versatility for the future of bioenergy. Curr. Opin.Biotechnol. 23: 346-351.

[23] Liau, B. C., Shen, C. T., Liang, F. P., Hong, S. E., Hsu, S. L., Jong, T. T., and Chang, C. M. 2010. Supercritical fluids extraction and anti-solvent purification of carotenoids from microalgae and associated bioactivity. J. Supercrit. Fluids. 55: 169175.

[24] Licht, F. O. 2006. World ethanol markets: the outlook to 2015. Tunbridge Wells, Agra Europe special report, $\mathrm{UK}$.

[25] Mussatto, S. I., Dragone, G., Pedro M. R., Guimarães, J. P. A., Silva, L. M., Carneiro, I. C. Roberto, A. V., Lucília D., José, A. 2010. Teixeira. Technological trends, global market, and challenges of bio-ethanol production. Biotechnol.Adv. 28: 817830.

[26] Pimentel, D. 2003. Ethanol fuels: energy balance, economics, and environmental impacts are negative. Natural Res Res. 12: 127-34.

[27] Pimentel, D., Patzek, T. W. 2005. Ethanol production using corn, switchgrass, and wood; biodiesel production using soybean and sunflower. Natural Res Res. 14: 65-76.

[28] Prasad, S., Singh, A., Jain, N., Joshi, H. C. 2007a. Ethanol production from sweet sorghum syrup for utilization as automotive fuel in India. Energy Fuels. 21: $2415-2420$.

[29] Prasad, S., Singh, A., Joshi, H. C. 2007b. Ethanol as an alternative fuel from agricultural, industrial and urban residues. Resour Conserv Recy. 50: 1-39.

[30] Rösch, C., Skarka, J., and Wegerer, N. 2012. Materials Flow Modeling of Nutrient Recycling in Biodiesel Production from Microalgae. Bioresour. Technol, 107, 191-199.

[31] Rosillo-Calle, F., Cortez, L. 1998. Towards proalcohol II: a review of the Brazilian bioethanol programme. Biomass Bioenergy, 14,115-124.

[32] Sawayama, S., Inoue, S., Dote, Y., Yokoyama, S. Y. 1995. $\mathrm{CO}_{2}$ fixation and oil production through mi- croalga. Energy Convers.Manage. 36: 729-31.

[33] Schenk, P. M., Thomas-Hall, S. R., Stephens, E., Marx, U. C., Mussgnug, J. H., Posten, C., Kruse, O., Hankamer, B. 2008. Second generation biofuels: high-efficiency microalgae for biodiesel production. Bioenergy Res. 1: 20-43.

[34] Singh, A., Nigam, P. S., Murphy, J. D. 2010c. Mechanism and challenges in commercialisation of algal biofuels. Bioresour. Technol. doi:10.1016/ j.biortech .2010 .06 .057 .

[35] Singh, A., Nigam, P. S., Murphy, J. D. 2011. Renewable fuels from algae: An answer to debatable land based fuels. Bioresource Technol. 102: 10-16.

[36] Singh, A., Pant, D., Korres, N. E., Nizami, A. S., Prasad, S., Murphy, J. D. 2010a. Key issues in life cycle assessment of ethanol production from lignocellulosic biomass: challenges and perspectives. Bioresour. Technol. 101: 5003-5012.

[37] Singh, A., Smyth, B. M., Murphy, J. D. 2010b. A biofuel strategy for Ireland with an emphasis on production of biomethane and minimization of landtake. Renew. Sustain. Energy Rev. 14: 277-288.

[38] Solomon, B. D., Barnes, J. R., Halvorsen, K. E. 2007. Grain and cellulosic ethanol: history, economics, and energy policy. Biomass Bioenergy. 31: 41625.

[39] Tan, R. R., Foo, D. C. Y., Aviso, K. B., Ng, D. K. S. 2009. The use of graphical pinch analysis for visualizing water footprint constraints in biofuel production. Appl Energy. 86: 605-9.

[40] Tatli Z. H. 2009. Computer based education: Online learning and teaching facilities. Energy Educ Sci Technol Part B. 1: 171-81.

[41] Wi, S. G., Kim, H. J., Mahadevan, S. A., Yang, D. J., Bae, H. J. 2009. The potential value of the seaweed Ceylon moss (Gelidium amansii) as an alternative bioenergy resource. Bioresour.Technol. 100: 6658-6660.

[42] Yanagisawa, M., Nakamura, K., Ariga, O., Nakasaki, K. 2011. Production of high concentrations of bioethanol from seaweeds that contain easily hydrolyzable polysaccharides

[43] Yoon, J. J., Kim, Y. J., Kim, S. H., Ryu, H. J., Choi, J. Y., Kim, G. S., Shin, M. K. 2010. Production of polysaccharides and corresponding sugars from red seaweed. Adv Mater Res. 93-94: 463-466. 